\title{
PENGARUH PENERAPAN MODEL PEMBELAJARAN KOLABORATIF TEKNIK GROUP INVESTIGATION TERHADAP KEMAMPUAN BERPIKIR ANALISIS PESERTA DIDIK
}

\section{THE EFFECT OF IMPLEMENTATION COLLABORATIVE LEARNING MODEL OF GROUP INVESTIGATION TECHNIQUES ON ANALITICAL THINKING SKILLS OF STUDENTS}

\author{
Hayatin Nisa, Disman, Dadang Dahlan \\ Email: hayatinnisa@student.upi.edu; disman@upi.edu; dadangdahlan@upi.edu
}

\begin{abstract}
ABSTRAK
Tiga tujuan pembelajaran yaitu domain kognitif, afektif dan psikomotor. Domain kognitif meliputi tujuan yang berhubungan dengan ingatan (recall), pengetahuan dan kemampuan intelektual. Kemampuan analisis merupakan kemampuan yang termasuk dalam tujuan belajar ranah kognitif setelah pengetahuan, pemahaman, dan aplikasi. Kemampuan analisis adalah kemampuan untuk merinci atau menguraikan suatu masalah (soal) menjadi bagian-bagian yang lebih kecil (komponen) serta mampu untuk memahami hubungan diantara bagian-bagian tersebut. Kemampuan analisis merupakan salah satu kemampuan berpikir tingkat tinggi yang penting dan harus dimiliki peserta didik. Kemampuan berpikir analisis dapat diasah dengan latihan. Semakin sering melakukan latihan, maka seseorang semakin terlatih dalam berpikir analisis. Melatih berpikir analisis bisa dengan menerapkan model pembelajaran kolaboratif. Pembelajaran kolaboratif dalam konteks pendidikan dipuji secara luas sebagai praktik yang mampu mengembangkan dan meningkatkan kualitas proses belajar mengajar. Model pembelajaran kolaboratif dengan teknik penyelesaian masalah (Problem Solving) seperti teknik Group Investigation (Investigasi Kelompok) dapat mendorong peserta didik berpikir analisis, serta terampil memecahkan masalah dan isu dunia nyata.
\end{abstract}

Kata Kunci: Kemampuan Berpikir Analisis, Teknik Group Investigation

\begin{abstract}
Three learning objectives are cognitive, affective and psychomotor domains. Cognitive domains include goals relating to recall, knowledge and intellectual ability. Ability analysis is an ability that is included in the learning objectives of the cognitive domain after knowledge, understanding, and application. Ability analysis is the ability to break down or decipher a problem (matter) into smaller parts (components) and be able to understand the relationship between the parts. Ability analysis is one of the high-level thinking skills that are important and must be possessed learners. Analytical thinking ability can be sharpened with practice. The more you practice, the more you are trained in analytical thinking. Train analytical thinking can be by applying collaborative learning models. Collaborative learning in the educational context is widely praised as a practice that is able to develop and improve the quality of teaching and learning. Collaborative learning models with problem solving techniques such as Group Investigation techniques can encourage learners to think about analysis, as well as skillfully solve real-world problems and issues.
\end{abstract}

Keywords: Analytical Thinking Skills, Group Investigation Techniques 


\section{A. Latar Belakang Penelitian}

Seiring perkembangan zaman maka ilmu pengetahuan dan teknologi juga berkembang dengan pesat sehingga menuntut adanya sumber daya manusia yang berkualitas tinggi yang dapat menjadi faktor pendorong berkembangnya suatu Negara (Art-in, 2014). Pendidikan merupakan salah satu pilar penting dalam peningkatan kualitas sumber daya manusia (SDM) dan kesejahteraan hidup masyarakat (Maher, 2004:3).

Upaya meningkatkan mutu pendidikan membutuhkan proses belajar mengajar yang optimal sehingga diperoleh hasil belajar sesuai dengan tujuan yang diharapkan. Maka tujuan fundamental dari pendidikan sesuai dengan Undang-Undang Republik Indonesia Nomor 20 tahun 2003 tentang Sistem Pendidikan Nasional (Agus, Adnyana, Suarni, \& Koyan, 2014). Menyadari pentingnya pencapaian tujuan pendidikan, berbagai upaya sudah dilakukan sekolah untuk meningkatkan mutu pendidikan, baik secara fisik maupun mental dalam rangka mengimbangi kemajuan ilmu pengetahuan dan teknologi yang semakin pesat. Sekolah sebagai organisasi yang menyelenggarakan proses pendidikan secara formal mempunyai peranan yang sangat besar bagi terwujudnya sumber daya manusia yang berkualitas (Purwanto, 2012).

Untuk mewujudkan hal tersebut maka sesuai dengan fokus kurikulum 2013 (revisi terbaru) bahwa perlu mengintegrasikan HOTS (Higher Order Thinking Skill) atau kemampuan berfikir tingkat tinggi level C4 s/d C6. Higher Order Thinking Skill (HOTS) adalah kemampuan berfikir kritis, logis, reflektif, metakognitif yang mensyaratkan peserta didik mampu untuk memprediksi, mendesain dan memperkirakan. Sejalan dengan itu ranah dari HOTS meliputi kemampuan menganalisis, kemampuan mengevaluasi dan dan kemampuan mengkreasi (Istiyono, Mardapi, \& Suparno, 2014).

Kemampuan menganalisis, kemampuan mengevaluasi dan kemampuan mengkreasikan merupakan aspek berpikir tingkat tinggi yang perlu dibiasakan. Kemampuan berpikir analisis merupakan kemampuan yang perlu dimiliki oleh peserta didik sebelum sampai kepada tahap berpikir evaluasi dan kreasi. Kemampuan berpikir analisis dapat diartikan sebagai kemampuan untuk membedakan berbagai elemen dari sesuatu hal dan menjelaskan alasan hubungan antara elemen-elemen tersebut untuk menemukan penyebab sebenarnya (Chareonwongsak dalam (Montaku, 2011)).

Namun pada kenyataannya, berpikir tingkat tinggi peserta didik masih rendah. Hal tersebut dapat dilihat dari hasil survey The Trends in International Mathematics and Science Study (TIMSS) yang mengukur kategori peserta didik dapat mengorganisasikan informasi, membuat perumuman, memecahkan masalah tidak rutin, mengambil dan mengajukan argument pembenaran simpulan. Hasil survey menunjukkan Indonesia menempati posisi 45 dari 48 negara (Puspendik Kemdikbud, 2016). Berdasarkan hasil survei PISA tahun 2012 Indonesia hanya sedikit lebih baik dari Peru yang berada di ranking terbawah. Ratarata skor matematika anak-anak Indonesia 375. Indonesia hanya menduduki rangking 64 dari 65 negara dengan rata-rata skor 375, sementara ratarata skor internasional adalah 500 (OECD dalam (Kurniati, Harimukti, \& Jamil, 2016) Hal ini menunjukkan kemampuan siswa Indonesia dalam menyelesaikan soal-soal yang menuntut kemampuan analisis, evaluasi, kreasi, serta logika dan penalaran sangat kurang.

Mengukur kemampuan berpikir analisis peserta didik harus menggunakan soal-soal yang dapat mengukur kemampuan berpikir analisis. Kemampuan analisis merupakan salah satu kemampuan berpikir tingkat tinggi yang penting dan harus dimiliki peserta didik (Areesophonpichet, 2013; Perwitasari, Sumarmi, \& Amirudin, 2016). Kemampuan analisis akan menjadi alat penting bagi peserta didik untuk diterapkan dalam pekerjaannya dan diperlukan dalam kegiatan kehidupan sehari-hari (Art-in, 2014, 2015). Meningkatkan keterampilan peserta didik dalam menganalisa dapat ditemukan sebagai tujuan dalam banyak bidang studi. Studi sains, studi sosial, humaniora, dan seni sering mengekspresikan "belajar untuk menganalisis" sebagai salah satu tujuan penting bagi pendidikan (Mayer, 2002).

Kemampuan berpikir analisis dapat diasah dengan latihan (Perwitasari et al., 2016). Semakin sering melakukan latihan, maka seseorang semakin terlatih dalam berpikir analisis. 
Berpikir analisis peserta didik dapat diterapkan di dalam berbagai materi pembelajaran. Salah satunya pada mata pelajaran ekonomi. Mata pelajaran ekonomi di sekolah menengah atas tidak hanya berorientasi pada isi dan materi pelajaran (subject matter oriented) yang memaksa peserta didik untuk memahami dan menerima materi pelajaran sebagai ilmu. Pembelajaran ekonomi harus memudahkan peserta didik untuk mampu membuat pilihan-pilihan secara rasional dan membuat peserta didik dapat menggunakan konsep-konsep dalam pembelajaran ekonomi untuk menganalisis persoalan-persoalan ekonomi personal dan kemasyarakatan. Metode pemecahan masalah yang digunakan dalam pembelajaran ekonomi diturunkan dari metode- metode ilmiah, yang menekankan pada analisis atas dasar logika agar dapat diterapkan dalam pembelajaran ekonomi.

Berbagai upaya diperlukan dalam meningkatkan proses pembelajaran di sekolah dengan merencanakan pelajaran dan menggunakan bahan ajar serta mengembangkan model, pendekatan, strategi dan metode pembelajaran yang tepat untuk mengembangkan kemampuan berpikir analisis peserta didik (Areesophonpichet, 2013). Model pembelajaran yang tepat adalah model pembelajaran yang memperhatikan karakteristik peserta didik dengan melibatkan peserta didik secara penuh (student center) sehingga memperoleh pengalaman dalam menuju kedewasaan, dapat melatih kemandirian, serta dapat belajar dari lingkungan kehidupannya (Sholikhah, Budiyono, \& Saputro, 2014).

Model pembelajaran kolaboratif merupakan maka upaya yang tepat untuk meningkatkan cognitive skill dan kemampuan berpikir tingkat tinggi terutama kemampuan berpikir analisis dalam pembelajaran ekonomi. Pembelajaran kolaboratif telah banyak digunakan dalam pengajaran matematika, sains, studi sosial, bahasa, dan banyak subjek lainnya (Oxford, 1997). Pembelajaran kolaboratif dalam konteks pendidikan dipuji secara luas sebagai praktik yang mampu mengembangkan dan meningkatkan kualitas proses belajar mengajar (Nordentofl \& Wistoft, 2013). Model pembelajaran kolaboratif adalah perpaduan dua atau lebih pelajar yang bekerja bersamasama dan berbagi beban kerja secara setara sembari secara perlahan mewujudkan hasil pembelajaran yang diinginkan. Model pembelajaran kolaboratif dengan teknik penyelesaian masalah (Problem Solving) dapat mendorong peserta didik berpikir analisis, serta terampil memecahkan masalah dan isu dunia nyata seperti teknik Group Investigation (Investigasi Kelompok) (Barkley, Cross, \& Major, 2014).

Group investigation (investigasi kelompok) merupakan pembelajaran kelompok dimana peserta didik bekerja kedalam kelompok-kelompok kecil dengan menggunakan investigasi kelompok, diskusi kelompok, serta perencanaan dan proyek kelompok, dan kemudian melakukan pemaparan kepada seluruh kelas tentang temuan mereka (R.E. Slavin, 2011). Teknik pembelajaran ini melatih kerjasama dan tanggung jawab peserta didik dengan secara langsung melakukan penyelidikan, mempresentasikannya kemudian mengevaluasi hasil kerja kelompoknya. Seperti yang terkesan dari namanya, group investigation sesuai untuk proyek-proyek studi yang terintegrasi tang berhubungan dengan hal-hal semacam penguasaan, analisis, dan mensintesiskan informasi sehubungan dengan upaya menyelesaikan masalah yang bersifat multi-aspek (Robert E. Slavin, 2005). Pembelajaran Group Investigation terbukti lebih unggul dalam meningkatkan hasil belajar peserta didik dibandingkan dengan teknik pembelajaran yang digunakan selama ini (Gianto, 2016).

\section{Rumusan Masalah}

Berdasarkan pernyataan masalah di atas, masalah dalam penelitian ini secara spesifik dirumuskan dalam pertanyaan penelitian sebagai berikut:

1. Bagaimanakah pengaruh model pembelajaran kolaboratif teknik group investigation terhadap kemampuan berpikir analisis peserta didik?

\section{Tujuan Penelitian}

Secara khusus, tujuan yang ingin dicapai melalui penelitian ini adalah sebagai berikut:

1. Untuk mengetahui pengaruh model pembelajaran kolaboratif teknik group investigation terhadap kemampuan berpikir analisis peserta didik 


\section{Manfaat Penelitian}

Manfaat yang diharapkan dari hasil penelitian ini ada dua macam, manfaat secara teoritis dan manfaat secara praktis. Secara Teoritis, hasil penelitian ini berguna untuk memberikan sumbangan kepada dunia pendidikan dalam pembelajaran ekonomi terutama untuk meningkatkan kemampuan berpikir analisis peserta didik dengan menggunakan model pembelajaran kolaboratif teknik teknik Group Investigation.

Secara praktis, hasil penelitian ini diantaranya berguna: 1) bagi peserta didik untuk meningkatkan kemampuan berpikir analisis dalam pembelajaran ekonomi, 2) bagi guru untuk mengembangkan model/metode pembelajaran yang kreatif serta meningkatkan kemampuan menciptakan dan mempertahankan kondisi kelas yang dikehendaki atau kondisi ideal dalam pelaksanaan pembelajaran ekonomi di kelas, 3) bagi sekolah untuk memberikan kontribusi dalam rangka peningkatan berpikir analisis peserta didik yang mengarah kepada perbaikan hasil belajar peserta didik, 4) bagi peneliti untuk dijadikan bahan referensi untuk melakukan penelitian sejenis

\section{B. TINJAUAN PUSTAKA}

1. Teori Belajar yang Melandasi Model Pembelajaran Kolaboratif

Teori yang melandasi pembelajaran kolaboratif adalah teori konstruktivisme social (L.Lin, 2015; Nordentofl \& Wistoft, 2013). Teori konstruktivisme lahir dari gagasan kognitif Jean Piaget dan Lev Semonovich Vigotsky. Dalam proses pembelajarannya, konstruktivisme memiliki pandangan utama yang membedakannya dengan teori-teori yang lain, yaitu bahwa pengetahuan tidak bisa di transfer atau dipindahkan begitu saja dari pendidik ke peserta didik (Anwar, 2017). Konstruktivisme adalah persfektif psikologis dan filosofis yang memandang bahwa masing-masing individu membentuk dan membangun sebagian besar dari apa yang mereka pelajari dan pahami (Bruning, Schraw, Norby, \& Ronning, 2004). Konstruktivisme tidak mengemukakan bahwa prinsip-prinsip pembelajaran ada dan harus ditemukan serta diuji, tetapi mengetengahkan bahwa peserta didik menciptakan pembelajaran mereka sendiri (Schunk, 2012).

Menurut Piaget dalam Schunk (2012) perkembangan pengetahuan (kognitif) seseorang tergantung pada empat faktor yaitu, pertumbuhan biologis; pengalaman dengan lingkungan fisik; pengalaman dengan lingkungan social; dan ekuilibrasi. Tiga faktor pertama efek-efeknya bergantung pada ekuilibrasi. Seperti teori Piaget, teori Vygotsky juga sebuah teori konstruktivis, tetapi Vygotsky menempatkan lebih banyak penekanan pada lingkungan social sebagai fasilitator perkembangan dan pembelajaran (Tudge \& Scrimsher, 2003). Dalam teorinya Vygosky mengatakan bahwa inti konstruktivis adalah interaksi antara aspek internal dan aspek eksternal yang penekanannya pada lingkungan social dalam belajar. Vygotsky sangat menekankan pentingnya peranan lingkungan kebudayaan dan interaksi sosial dalam perkembangan sifat-sifat dan tipe-tipe manusia (R.E. Slavin, 2000).

Peserta didik mempunyai dua tingkat perkembangan, yaitu tingkat perkembangan actual (actual development) dan tingkat perkembangan potensial (potensial development) (Vygotsky dalam (Widjajanti:2008). Zona antara tingkat perkembangan aktual dan tingkat perkembangan potensial itulah yang disebut dengan zona perkembangan terdekat atau ZPD. Konsep zone of proximal development (ZDP) didefinisikan sebagai jarak antara level perkembangan actual yang ditentukan melalui problem solving secara mandiri dan level potensi perkembangan yang ditentukan melalui problem solving dengan bantuan orang dewasa atau dengan kerja sama dengan teman-teman sebaya yang lebih mampu (Nyikos \& Hashimato, 1997; Wood \& Wood, 2006). Bantuan kepada peserta didik dalam kondisi ZPD inilah yang selanjutnya disebut sebagai scaffolding.

Konsep pembelajaran kolaboratif sebagian besar berakar pada teori konstruktivisme sosial Vygotsky yang memandang belajar secara inheren merupakan proses sosial yang diaktifkan melalui Zona Pengembangan Proksimal (ZPD) dan Scaffolding (Dillenbourg,1999 dalam (L.Lin, 2015)). Pandangan sosiokultural Vygotsky telah memberikan kontribusi signifikan terhadap epistemologi konstruktivis sosial dan sorotan bagaimana belajar dimediasi sesuai dengan konteks 
dan pengalaman dengan teman sebayanya. Kedua konsep yang diutarakan oleh Vygotsky yaitu ZPD dan scaffolding dalam teori konstuktivisme social menjadi landasan teori bagi pembelajara kolaboratif.

\section{Model Pembelajaran Kolaboratif}

Pembelajaran kolaboratif merupakan suatu model pembelajaran yang sering digunakan dalam proses pembelajaran (Brassard, 2010; Cho \& Lim, 2015; Silverman, 1995; Wilhelm, 1997). Pembelajaran kolaboratif telah banyak digunakan dalam pengajaran matematika, sains, studi sosial, bahasa, dan banyak subjek lainnya (Oxford, 1997). Dalam pembelajaran kolaboratif, pembelajaran dilakukan dalam interaksi antar pihak yang berpartisipasi dalam suatu interaksi (Nordentofl \& Wistoft, 2013). Pembelajaran bergantung pada partisipasi dan orientasi terhadap praktik sosial dalam konteks tertentu (Marsh \& Tainio, 2009). Kegiatan sosial yang terstruktur dan pastisipasi yang terstruktur itulah yang dikatakan pembelajaran kolaboratif. Dalam setting pembelajaran kolaboratif peserta didik memiliki kesempatan untuk berkomunikasi dengan teman sebaya, mempresentasikan dan membela gagasan, bertukar pemikiran yang beragam, mempertanyakan kerangka konseptual lainnya, dan terlibat secara aktif (Srinivas,2011 dalam (Laal \& Laal, 2014).

Pembelajaran kolaboratif sebagai salah satu hal yang paling penting dan paling efektif sebagai sarana untuk belajar dapat berlangsung, dan fokus pada eksplorasi bersama subjek melalui interaksi sosial dengan teman sebaya dan antara peserta didik dan guru (Swain,1997 dalam (L.Lin, 2015)). Pembelajaran kolaboratif didasarkan pada epistemologi yang berbeda dan berasal dari konstruktivisme social (Barkley et al., 2014).

Pembelajaran kolaboratif merujuk pada kegiatan pembelajaran yang sengaja dirancang dan dilaksanakan secara berpasangan atau dalam kelompok kecil. Pembelajaran kolaboratif terjadi ketika kelompok kecil peserta didik saling membantu untuk belajar (Laal \& Laal, 2014). Ketika pembelajaran kolaboratif digunakan untuk mendukung pengajaran, peserta didik cenderung lebih terlibat, mempertahankan informasi dengan lebih baik, dan memiliki hasil belajar yang lebih baik daripada peserta didik secara individual (McLaren, 2014).

Pembelajaran kolaboratif biasanya melibatkan peserta didik yang bekerja sama yang memiliki kedudukan yang relatif setara (yaitu, usia atau kelas yang sama dan mendekati tingkat pemahaman topik yang sama). Berkolaborasi peserta didik juga biasanya berbagi tujuan yang sama atau hasil yang diharapkan dalam bekerja sama (Johnson \& Johnson, 1994 dalam (McLaren, 2014)). Kelompok belajar kolaboratif dapat berkisar dari sepasang peserta didik (disebut dued), kelompok kecil (3-5 peserta didik), hingga kelas belajar (25-35 peserta didik), hingga pembelajaran online berskala besar (ratusan atau bahkan ribuan peserta didik) (McLaren, 2014).

\section{Teknik Group Investigation}

Group investigation merupakan teknik pembelajaran yang dikembangkan oleh Sholomo Sharan dan Yael Sharan di Universitas Tel Aviv, Israel (Doymus \& Akcay, 2010; Sherman, 1988). Pembelajaran group investigation merupakan teknik pembelajaran yang mengarahkan berfikir tingkat tinggi, dimana peserta didik dapat menghasilkan perbedaan dari hasil menganalisis dan evaluasi (Shachar \& Sharan, 2012). Berdasarkan pandangan konstruktivistik, proses pembelajaran dengan group investigation memberikan kesempatan seluas-luasnya kepada peserta didik untuk terlibat secara langsung dan aktif dalam proses pembelajaran mulai dari perencanaan sampai cara mempelajari suatu topic melalui investigasi.

Group Investigation adalah teknik pembelajaran yang dirancang untuk membimbing peserta didik dalam memperjelas masalah, menelusuri berbagai perspektif dalam masalah tersebut, dan mengkaji bersama untuk menguasai informasi, gagasan, dan skill yang secara simultan juga dapat mengembangkan kompetensi social mereka (Joice, Well, \& Calhoun, 2000). Group Investigation menekankan kegiatan investigasi untuk mendorong beberapa keterampilan seperti analisis, sintesis, dan pengumpulan informasi untuk memecahkan masalah (Slavin, 2005 dalam (Asyari, Muhdhar, Susilo, \& Ibrohim, 2016)). Dalam group investigation, kelompok peserta didik 
merencanakan, melaksanakan dan melaporkan proyek riset-riset yang mendalam (Barkley et al., 2014).

Langkah-langkah pembelajaran group investigation (Barkley et al., 2014) yaitu 1) Minta peserta didik melakukan sumbang saran untuk menetukan topic-topic yang sesuai; 2) Pilih topic yang akan di investigasikan dari daftar yang telah dibuat oleh peserta didik; 3) Bentuk kelompok berdasarkan ketertarikan pada topic; 4) Beri waktu kepada kelompok untuk mengatur usaha mereka seperti mempersiapkan prospectus dimana mereka memformulasikan persoalan-persoalan riset mereka, mengidentifikasi tujuan dan sumber-sumber yang mereka butuhkan untuk melakukan investigasi. Pilih metode investigasi mereka kemudian bagikan dan berikan tugasnya; 5) Minta kelompok memulai investigasi mereka, mengumpulkan informasi, mengulasnya dan memutuskan apakah diperlukan lebih banyak informasi serta menganalisis dan menginterpretasikan informasi tersebut; 6) Minta kelompok mempersiapkan laporan akhir

\section{Kemampuan Berpikir Analisis}

Kemampuan analisis merupakan kemampuan yang termasuk dalam tujuan belajar ranah kognitif setelah pengetahuan, pemahaman, dan aplikasi. Dalam taksonomi Bloom kemampuan analisis termasuk dalam ranah kognitif tingkat keempat (C4) (Kusumaningrum \& Saefudin, 2012). Kemampuan analisis merupakan kemampuan yang termasuk dalam tujuan belajar ranah kognitif setelah pengetahuan, pemahaman, dan aplikasi. Dalam taksonomi Bloom kemampuan analisis termasuk dalam ranah kognitif tingkat keempat (C4) (Kusumaningrum \& Saefudin, 2012).

Kemampuan analisis ini tidak mungkin dicapai peserta didik apabila peserta didik tersebut tidak menguasai aspek-aspek kognitif sebelumnya. Kemampuan untuk merinci atau menguraikan suatu masalah (soal) menjadi bagian-bagian yang lebih kecil (komponen) serta mampu untuk memahami hubungan diantara bagian-bagian tersebut merupakan pengertian kemampuan analisis (Suherman \& Sukjaya, 1990; Winarti, 2015).

Kemampuan analisis sebagai tujuan pembelajaran menurut taksonomi Bloom, dapat dibagi menjadi tiga sub katagori, yaitu penurunan dari kemampuan analisis yang mencakup (Amalia, 2016; Art-in, 2014; Kusumaningrum \& Saefudin, 2012; Kuswana, 2012):

a. Analisis tentang bagian-bagian (Membedakan)

Membedakan bagian yang relevan dan yang tidak relevan atau dari bagian yang penting ke bagian yang tidak penting dari suatu materi yang diberikan. Membedakan, terjadi ketika peserta didik dapat menentukan potongan-potongan informasi yang relevan dan penting. Nama-nama lain untuk membedakan adalah menyendirikan, memilah, memfokuskan, dan memilih

b. Analisis tentang hubungan-hubungan (Menghubungkan/Mengatribusikan)

Mengatribusikan berarti menentukan inti atau menggarisbawahi suatu materi yang diberikan. Menghubungkan, terjadi ketika peserta didik dapat menghubungkan potongan informasi dari proses pengorganisasian dengan tujuan dibalik informasi tersebut sehingga didapatkan inti atau menggaris bawahi suatu materi yang diberikan.

c. Analisis prinsip-prinsip pengorganisasian (Mengorganisasikan)

Mengorganisasi berarti menentukan bagaimana suatu bagian elemen tersebut cocok dan dapat berfungsi bersama-sama di dalam suatu struktur. Mengorganisasi terjadi ketika peserta didik dapat menyusun dan menentukan cara bagaimana potongan-potongan informasi menjadi satu kesatuan. Nama-nama lain untuk mengorganisasi adalah menemukan koherensi, memadukan, membuat garis besar, mendeskripsikan peran dan menstrukturkan

\section{METODOLOGI PENELITIAN}

Metode yang digunakan dalam penelitian ini adalah metode deskriptif. Metode ini menggambarkan penggunaan model pembelajaran kolaboratif teknik group investigation untuk meningkatkan kemampuan berpikir analisis. Data dikumpulkan dengan melakukan penelitian kepustakaan melalui pengumpulan data sekunder dan sumber publikasi lainnya yang relevan. 


\section{HASIL DAN PEMBAHASAN}

Fokus kurikulum 2013 (revisi terbaru) bahwa perlu mengintegrasikan HOTS (Higher Order Thinking Skill) atau kemampuan berfikir tingkat tinggi level C4 s/d C6. Ranah dari HOTS yaitu analisis yang merupakan kemampuan berfikir dalam menspesifikasi aspek-aspek atau elemen dari sebuah kontens tertentu; evaluasi merupakan kemampuan berpikir dalam mengambil keputusan berdasarkan fakta/informasi; dan mengkreasi merupakan kemampuan berpikir dalam membangun gagasan/ide-ide (Istiyono et al., 2014). Kemampuan berpikir analisis merupakan kemampuan yang perlu dimiliki oleh peserta didik sebelum sampai kepada tahap berpikir evaluasi dan kreasi.

Kemampuan analisis merupakan suatu kemampuan dasar yang harus dimiliki oleh peserta didik. Meningkatkan keterampilan peserta didik dalam menganalisa dapat ditemukan sebagai tujuan dalam banyak bidang studi. Studi sains, studi sosial, humaniora, dan seni sering mengekspresikan "belajar untuk menganalisis" sebagai salah satu tujuan penting bagi pendidikan (Mayer, 2002). Gambaran tentang kemampuan analisis peserta didik, yaitu: 1) menentukan keterhubungan antara satu kelompok informasi dengan informasi yang lainnya; 2) menentukan pokok-pokok pikiran yang mendasari suatu informasi; dan 3) kemampuan peserta didik dalam menarik konsekuensi dari informasi baik dalam waktu maupun dimensi (Hasan, 1996).

Kemampuan analisis adalah pemecahan dan penguraian suatu materi menjadi unsur-unsur penyusunnya sehingga menjadi bagian itu sendiri serta hubungan antara bagian untuk memperoleh pengertian yang tepat dan pemahaman dari arti keseluruhan (Bloom, 1959:114). Kemampuan berpikir analisis dapat diasah dengan latihan (Perwitasari et al., 2016). Semakin sering melakukan latihan, maka seseorang semakin terlatih dalam berpikir analisis.

Melatih berpikir analisis bisa dengan menerapkan model pembelajaran kolaboratif. Pembelajaran kolaboratif dalam konteks pendidikan dipuji secara luas sebagai praktik yang mampu mengembangkan dan meningkatkan kualitas proses belajar mengajar (Nordentofl \& Wistoft, 2013). Model pembelajaran kolaboratif dengan teknik penyelesaian masalah (Problem Solving) seperti teknik Group Investigation (Investigasi Kelompok) dapat mendorong peserta didik berpikir analisis, serta terampil memecahkan masalah dan isu dunia nyata (Barkley et al., 2014).

Pembelajaran group investigation merupakan teknik pembelajaran yang mengarahkan berfikir tingkat tinggi, dimana peserta didik dapat menghasilkan perbedaan dari hasil menganalisis dan evaluasi (Shachar \& Sharan, 2012). Group Investigation menekankan kegiatan investigasi untuk mendorong beberapa keterampilan seperti analisis, sintesis, dan pengumpulan informasi untuk memecahkan masalah (Slavin, 2005 dalam (Asyari et al., 2016)). Dalam group investigation, kelompok peserta didik merencanakan, melaksanakan dan melaporkan proyek riset-riset yang mendalam (Barkley et al., 2014). Pembelajaran Group Investigation terbukti lebih unggul dalam meningkatkan hasil belajar peserta didik dibandingkan dengan teknik pembelajaran yang digunakan selama ini (Gianto, 2016).

\section{E. KESIMPULAN DAN SARAN \\ Kesimpulan}

Teknik pembelajaran ini melatih kerjasama dan tanggung jawab peserta didik dengan secara langsung melakukan penyelidikan, mempresentasikannya kemudian mengevaluasi hasil kerja kelompoknya. Pembelajaran group investigation merupakan teknik pembelajaran yang mengarahkan berfikir tingkat tinggi, dimana peserta didik dapat menghasilkan perbedaan dari hasil menganalisis dan evaluasi (Shachar \& Sharan, 2012). Berdasarkan pandangan konstruktivistik, proses pembelajaran dengan group investigation memberikan kesempatan seluas-luasnya kepada peserta didik untuk terlibat secara langsung dan aktif dalam proses pembelajaran mulai dari perencanaan sampai cara mempelajari suatu topic melalui investigasi.

Group Investigation adalah teknik pembelajaran yang dirancang untuk membimbing peserta didik dalam memperjelas masalah, menelusuri berbagai perspektif dalam masalah tersebut, 
dan mengkaji bersama untuk menguasai informasi, gagasan, dan skill yang secara simultan juga dapat mengembangkan kompetensi social mereka (Joice et al., 2000). Group Investigation menekankan kegiatan investigasi untuk mendorong beberapa keterampilan seperti analisis, sintesis, dan pengumpulan informasi untuk memecahkan masalah (Slavin, 2005 dalam (Asyari et al., 2016)).

Dalam group investigation, kelompok peserta didik merencanakan, melaksanakan dan melaporkan proyek riset-riset yang mendalam (Barkley et al., 2014). Proyek-proyek ini memberikan kesempatan peserta didik mempelajari sebuah topik secara interaktif dan mendapat pengetahuan khusus mengenai suatu bidang tertentu. Apabila peserta didik telah menyelesaikan Group Investigation, pemahaman mereka terhadap arti penting penemuan menjadi semakin meningkat.

\section{Saran}

Berdasarkan kesimpulan yang telah dipaparkan, maka saran yang dapat penulis kemukakan yaitu:

1. Saran Bagi Peserta Didik

Peserta didik hendaknya lebih aktif dalam mengikuti pembelajaran di kelas agar dapat meningkatkan kemampuan berpikir tingkat tinggi (HOTS) terutama kemampuan berpikir analisis. Penggunaan model pembelajaran kolaboratif teknik group investigation diharapkan dapat meningkat kemampuan berpikir analisis peserta didik yang akan berdampak pada meningkatnya hasil belajar peserta didik.

2. Saran Bagi Guru

Guru hendaknya dapat menentukan model dan teknik pembelajaran yang tepat untuk meningkatkan kemampuan berpikir tingkat tinggi (HOTS) peserta didik

\section{Daftar Pustaka}

Agus, I. P., Adnyana, P., Suarni, N. K., \& Koyan, I. W. (2014). Pengaruh Penerapan Model Pembelajaran Kontekstual Berbasis Diskusi Kelompok Debat Terhadap Kemampuan Berpikir Analitik Mata Pelajaran PPKn Ditinjau dari Sikap Sosial Siswa X MM SMK PGRI 2 Badung. E-Journal Program Pascasarjana Universitas Pendidikan Ganesha, 4(2).

Amalia, R. (2016). Kemampuan Berpikir Matematis Mahasiswa dalam Menyelesaikan Masalah Geometri. Jurnal Pendidikan Matematika, 4 No.2, 118-125.

Anwar, C. (2017). Teori-Teori Pendidikan (1st ed.). Yogjakarta: IRCiSoD.

Areesophonpichet, S. (2013). A Development of Analytical Thinking Skills of Graduate Students by using Concept Mapping. The Asian Conference on Education, 1-16.

Art-in, S. (2014). The development of teacher training curriculum on learning management to develop students ' analytical thinking in Thailand. Procedia - Social and Behavioral Sciences, 116, 939-945. https://doi.org/10.1016/j.sbspro.2014.01.324

Art-in, S. (2015). Current Situation and Need in Learning Management for Developing the Analytical Thinking of Teachers in Basic Education of Thailand. Procedia - Social and Behavioral Sciences, 197(February), 1494-1500. https://doi.org/10.1016/j.sbspro.2015.07.100

Asyari, M., Muhdhar, M. H. I. Al, Susilo, H., \& Ibrohim. (2016). Improving critical thinking skills through the integration of problem based learning and group investigation. International Journal for Lesson and Learning Studies, 5 No. 1, 36-44. https://doi.org/10.1108/IJLLS-102014-0042

Barkley, E. E., Cross, K. P., \& Major, C. H. (2014). Colaborative Learning Techniques. Bandung: Nusa Media.

Bloom, et all. (1959). Taxonomy of Educational Objectives the Classifications of Educational Goals Handbook I: : Cognitive Domain. New York: David Mc Company, inc.

Brassard, C. (2010). The Collaborative Learning Model. Centre for Development of Teaching and Learning, 13(1), 1-14.

Bruning, R. H., Schraw, G. ., Norby, M. ., \& Ronning, R. . (2004). Cognitif Psychology and 
Instruction (4th ed.). Upper Saddle River, NJ: Merrill/ Prentice Hall.

Cho, Y. H., \& Lim, K. Y. T. (2015). Effectiveness of collaborative learning with 3D virtual worlds. British Journal of Educational Technology. https://doi.org/10.1111/bjet.12356

Doymus, K., \& Akcay, N. O. (2010). The Effects of Group Investigation and Cooperative Learning Techniques Applied in Teaching Force and Motion Subjects on Students Academic Achievements. Journal of Educational Sciences Research, 2(March 2016).

Gianto, A. . (2016). Peningkatan Kemampuan Memahami Cerita Wayang Tokoh Yudhistira Melalui Model Pembelajaran Group Investigation. Jurnal Penelitian Pendidikan Indonesia (JPPI), 1(2), 61-68.

Hasan, H. S. (1996). Pendidikan Ilmu-Ilmu Sosial. IKIP Bandung: Tidak Diterbitkan.

Istiyono, E., Mardapi, D., \& Suparno. (2014). Pengembangan Tes Kemampuan Berpikir Tingkat Tinggi Fisika (PysTHOTS) Peserta Didik SMA. Jurnal Pendidikan Dan Evaluasi Pendidikan, 18 No. 1, 1-12.

Joice, B., Well, M., \& Calhoun, E. (2000). Model of Teaching. Boston: A Pearson Education Company.

Kurniati, D., Harimukti, R., \& Jamil, N. A. (2016). Kemampuan Berpikir Tingkat Tinggi Siswa SMP di Kabupaten Jember dalam Menyelesaikan Soal Berstandar PISA. Jurnal Penelitian Dan Evaluasi Pendidikan, 20, No. 2(April). https://doi.org/10.21831/pep.v20i2.8058

Kusumaningrum, M., \& Saefudin, A. A. (2012). Mengoptimalkan Kemampuan Berpikir Matematika Melalui Pemecahan Masalah. Prosiding, (November), 978-979.

Kuswana, W. S. (2012). Taksonomi Kognitif Perkembangan Ragam Berpikir. Bandung: PT Remaja Rosdakarya.

L.Lin. (2015). Exploring Collaborative Learning: Theoretical and Conceptual Perspectives. https://doi.org/10.1007/978-3-662-44503-7

Laal, M., \& Laal, M. (2014). Collaborative learning: What is it? Social and Behavioral Sciences, 31(December 2012), 491-495. https://doi.org/10.1016/j.sbspro.2011.12.092

Maher, A. (2004). Learning outcomes in higher education: Implications for curriculum design and student learning. Leisure, Sport and Tourism Education, 3(2), 1-9. https://doi.org/10.3794/johlste.32.78

Marsh, A. P., \& Tainio, L. (2009). Scandinavian Journal of Educational Collaborative Game play as a Site for Participation and Situated Learning of a Second Language. Scandinavian Journal of Educational Research, 53 No. 2(October 2014), 37-41. https://doi.org/10.1080/00313830902757584

Mayer, R. E. (2002). Rote Versus Meaningful Learningi, 41(4).

McLaren, B. (2014). Collaborative Learning Whitepaper. Pennsylvania: Carnegie Mellon University.

Montaku, S. (2011). Results of analytical thinking skills training through students in system analysis and design course, (1934).

Nordentofl, H. M., \& Wistoft, K. (2013). Collaborative learning and competence development in school health nursing. Health Education, 112 No. 5, 448-468. https://doi.org/10.1108/09654281211253452

Nyikos, M., \& Hashimato, R. (1997). Constructivist Theory Amlied to Collaborative Learning in Teacher Education: In Search of ZPD. The Modern Language Journal, 81(4), 506-517. https://doi.org/10.1111/j.1540-4781.1997.tb05518.x

Oxford, R. L. (1997). Cooperative Learning, Collaborative Learning, and Interaction: Three Communicative Strands in the Language Classroom. The Modern Language Journal, 81(4), 443-456. https://doi.org/10.1111/j.1540-4781.1997.tb05510.x

Perwitasari, V. R. S., Sumarmi, \& Amirudin, A. (2016). Pengaruh Group Investigation Berbasis Outdoor Study Terhadap Kemampuan Berpikir Analisis Siswa. Jurnal Pendidikan Teori, Penelitian Dan Pengembangan, volume 1, 87-93. https://doi.org/http://dx.doi.org/10.17977/jp.v1i2.6107 
Purwanto, B. (2012). Eksperimentasi Model Pembelajaran Kooperatif Tipe Think-Talk-Write (TTW) dan Tipe Think-Pair-Share (TPS) Pada Materi Statistika Ditinjau Dari Kemandirian Belajar Siswa SMA Di Kabupaten Madiun.

Puspendik Kemdikbud. (2016). Hasil TIMSS 2015. Jakarta.

Schunk, D. H. (2012). Learning Theories (6th ed.). Yogyakarta: Pustaka Pelajar.

Shachar, H., \& Sharan, S. (2012). Talking, Relating, and Achieving: Effects of Cooperative Learning and Whole-Class Instruction, 12(4), 313-353.

Sherman, L. W. (1988). A Comparative Study Of Cooperative And Competitive Achievement In Two Secondary Biology Classrooms : The Group Investigation Model Versus An Individually Competitive Goal Structure. Journal of Research in Science Teaching, 26(1), 55-64.

Sholikhah, O. H., Budiyono, \& Saputro, D. R. S. (2014). Eksperimentasi Model Pembelajaran Kooperatif Tipe Group Investigation ( GI ) Dan Numbered Heads Together ( NHT ) Pada Materi Garis Singgung Lingkaran Ditinjau Dari Kecerdasan Majemuk Siswa Kelas VIII SMP Negeri Se-Kota Madiun Tahun Ajaran 2013/2014. Jurnal Elektronik Pembelajaran Matematika, 2(7), 727-739.

Silverman, B. G. (1995). Computer supported collaborative learning (CSCL). Computers Educ, 25(3), 81-91. https://doi.org/https://doi.org/10.1016/0360-1315(95)00059-3

Slavin, R. E. (2000). Educational Psychology: Theory and Practice (6th ed.). Boston: Allyn and Bacon.

Slavin, R. E. (2005). Cooperative Learning. Bandung: Nusa Media.

Slavin, R. E. (2011). Psikologi PendidikanTeori dan praktik. Jakarta: Permata Puri Media.

Suherman, E., \& Sukjaya, Y. (1990). Petunjuk Praktis untuk Melaksanakan Evaluasi Pendidikan Matematika. Bandung: wijayakusumah 157.

Tudge, J. R. H., \& Scrimsher, S. (2003). Lev S. Vygotsky on Education: A Cultural Historical, Interpersonal, and Individual Approach to Development. Dalam B.J Zimmerman \& D.H. Schunk (Ed), Educational Psychologyy: A century of contributions (hlm. 207-228). Mahwah, NJ: Erlbaum.

Widjajanti, D. B. (2008). Strategi Pembelajaran Kolaboratif Berbasis Masalah. Semnas Matematika Dan Pendidikan Matematika, (5), 101-110.

Wilhelm, K. H. (1997). Sometimes Kicking and Screaming : Language Teachers- \& Training React to a Collaborative Learning Model. The Modern Language Journal, 81, 527-543. https://doi.org/10.1111/j.1540-4781.1997.tb05522.x

Winarti. (2015). Profil Kemampuan Berpikir Analisis dan Evaluasi Mahasiswa dalam Mengerjakan Soal Konsep Kalor. Jurnal Inovasi Dan Pembelajaran Fisika, 2 No.1, 19-24.

Wood, D., \& Wood, H. (2006). Oxford Review of Education Vygotsky, Tutoring and Learning. Oxford Review of Education, 22 No.l(October 2014), 37-41. https://doi.org/10.1080/0305498960220101 